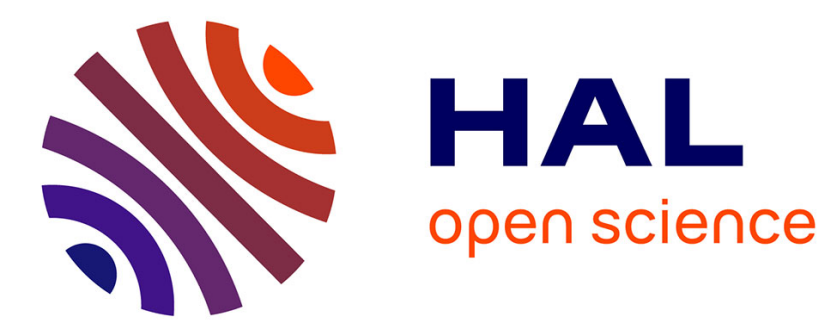

\title{
Urban colonies are more resistant to a trace metal than their forest counterparts in the ant Temnothorax nylanderi
}

L Jacquier, C Doums, A Four-Chaboussant, R Peronnet, C Tirard, M Molet

\section{- To cite this version:}

L Jacquier, C Doums, A Four-Chaboussant, R Peronnet, C Tirard, et al.. Urban colonies are more resistant to a trace metal than their forest counterparts in the ant Temnothorax nylanderi. Urban Ecosystems, 2020, 24 (3), pp.561-570. 10.1007/s11252-020-01060-9 . hal-03019372v2

HAL Id: hal-03019372

https://hal.sorbonne-universite.fr/hal-03019372v2

Submitted on 4 Dec 2020

HAL is a multi-disciplinary open access archive for the deposit and dissemination of scientific research documents, whether they are published or not. The documents may come from teaching and research institutions in France or abroad, or from public or private research centers.
L'archive ouverte pluridisciplinaire HAL, est destinée au dépôt et à la diffusion de documents scientifiques de niveau recherche, publiés ou non, émanant des établissements d'enseignement et de recherche français ou étrangers, des laboratoires publics ou privés. 
Urban colonies are more resistant to a trace metal than their forest counterparts in the ant

\section{Temnothorax nylanderi}

$$
\text { L. Jacquier }{ }^{1} \text {, C. Doums }{ }^{2} \text {, A. Four-Chaboussant }{ }^{3} \text {, R. Peronnet }{ }^{1}, \text { C. } \text { Tirard }^{1} \text {, M. Molet }{ }^{1}
$$

\footnotetext{
${ }^{1}$ Institute of Ecology and Environmental Sciences of Paris, Sorbonne Université, Paris, France
}

${ }^{2}$ EPHE, PSL Paris, France

${ }^{3}$ Master EBE, Sorbonne Université, Paris, France

Keywords: Urbanization, common garden, cadmium resistance, social insects

Abstract: Cities can be used as open-sky replicates to assess the responses of organisms to environmental changes, such as increased heat or pollution. In contrast with the numerous communitylevel studies, population-level studies are rare, hugely biased towards birds, and rarely based on multiple city replicates. They are also mostly based on solitary species, despite some social insects being ecologically dominant and economically important. Our study aimed at assessing whether colonies of the ant Temnothorax nylanderi from forest and urban populations exhibit distinct responses to pollution. We collected colonies from four pairs of forest and urban habitats and reared them in the laboratory under normal or cadmium-supplemented diets. We then measured the emergence rate and size of newlyproduced workers as well as the mortality rate of adult workers. We also assessed the effect of some social factors such as colony size or size of field workers. In all four forest/city replicates, urban colonies were less negatively affected by cadmium than forest colonies. We did not find any effect of social factors on cadmium resistance, in contrast with what was found in other eusocial insects. We discuss the potential adaptive nature of this differential response.

\section{Introduction}

United Nations predict that by 2030 , more than $60 \%$ of the worldwide human population will live in cities, resulting in a threefold increase of total urban areas (1). Urbanization is associated with many 
environmental changes, both abiotic and biotic (e.g. modified land use, habitat fragmentation, decreased soil permeability, increased temperatures known as Urban Heat Island effect, noise, light, and chemical pollutions including trace metals, exotic species (2-4)). Because these changes are quite fast and recent on the evolutionary timescale, cities can be seen as open sky laboratory replicates for understanding the responses of species facing rapid environmental changes $(5,6)$. Most studies investigating the impacts of urbanization on wildlife have been conducted at the community level, with a taxonomic skew toward birds, although fishes, lizards, amphibians, arthropods $(7-14)$ and plants $(15,16)$ have been occasionally studied. Urbanization alters the composition of communities (higher or lower species abundance), functional traits (e.g. reduced body size), and interaction networks (10-14,16-19). In contrast, specieslevel studies are less common (see (6) for a good summary) Relative to non-urban populations, animals from urban populations express altered behavior (e.g. songs with distinct pitches, loss of migratory behavior $(17,18)$ ), changes in physiology (e.g. lower glucocorticoid secretion in response to stress, higher oxidative stress (19)), phenology (earlier reproduction $(20,21)$ ), circadian rhythm (faster circadian oscillations (22)), health (higher parasitism rate (23)) and/or morphology $(7,24)$. These shifts in life-history traits are often seen as a response, adaptive or not, to urban stressors. However, because cities are extremely diverse and because most studies are based on a single city and not multiple city replicates (but see $(21,25)$ ), it is difficult to make general conclusions and identify a robust syndrome of urbanization for population-level traits. In addition, population studies are generally correlative $(17,24,26-34)$, and do not quantify the respective contributions of genetics and phenotypic plasticity. So far, common garden experiments between urban and non-urban populations highlighted a genetic basis for the lower dispersal ability of urban plants (15), earlier reproduction of urban birds and ants $(20,21)$ and for specific behaviors of urban birds (lower migratory behavior, increased boldness and stress). Additional common garden experiments are thus needed to complement correlative studies and assess causality and determination of various other life-history traits associated with urban life.

Pollution is one of the main chronic urban stressors. Urban habitats are usually more polluted because of traffic and industrial activities (35). For example, traffic-generated air pollution is responsible of increased oxidative stress leading to genetic damages, respiratory diseases and brain inflammation 
$(29,36,37)$ as well as higher susceptibility to parasites (23) in animals. Cities are also contaminated by trace metals. For example, cadmium has a concentration of $0.30 \mathrm{mg} \cdot \mathrm{kg}^{-1}$ in soil of rural woods and 2.45 mg.kg ${ }^{-1}$ in urban woods (35). Cadmium alters plant physiology by interfering with calcium uptake (38). It also impacts various life history traits, causing longer development in fishes and arthropods, decreased hatching rate in fishes, sea stars and arthropods (39-41), decreased body size in fishes (40) and immunosuppression in rats (42).

Ants represent a large portion of the total earth animal biomass (43). They are found in a large diversity of ecosystems including urban areas and can deeply affect the functioning of ecosystems (44-46). This ecological success partly originates from their social lifestyle. Ants live in colonies made of few tens to millions of individuals where labor is divided among individuals according to their caste. Eusociality could enhance robustness against environmental changes. For example, eusocial species of bees are less negatively impacted by neocotinoids than solitary species (47), and models suggest that, within species, larger colonies resist better to pesticides (48). In ants, social life enhances resistance to parasites and starvation $(49,50)$. In spite of their ecological interest and their social life, few studies investigating the effect of urbanization have been conducted on ants (5,51-53) and even fewer at the species level (54). How sociality could help ants resist anthropic stressors is an open question.

The aim of this study was to test whether there is a general effect of urbanization on resistance to trace metals (cadmium) in the small acorn ant Temnothorax nylanderi. Ants are a good model to study the effects of trace metals because they live in long-lived colonies and they forage locally around their nest, exposing themselves to bioaccumulation (55). We tested whether colonies of T. nylanderi from city and forest populations exhibit a differential response to pollution by feeding them with food enriched with cadmium or not, in a common garden laboratory setup, and by measuring several traits of the newly produced workers. We expected urban colonies to resist cadmium better because of their long history (several generations) of exposure to trace metal pollution relative to non-urban colonies. Moreover, this species offers the opportunity to assess the effects of social life on cadmium resistance, as colony size varies from less than ten to a few hundred individuals. The common-garden setup allowed to test for a 
causal link between the stressor and the observed shift in traits (mortality of adult workers, and emergence rate and size of newly produced workers).

\section{Material and methods}

\section{Colony collection and rearing}

Temnothorax nylanderi is a small ant with small colonies (up to few hundred workers) that nests in acorns and twigs on the ground. Colonies are easy to collect and rear in the laboratory, and they produce new workers in two months at $22-26^{\circ} \mathrm{C}$ cycle (56). Two hundred and thirty-eight colonies of $T$. nylanderi were collected from eight sites at three locations in France (Paris, Bordeaux, Lyon). Each location had one pair of collection sites: a central urban park (city habitat) and a forest located between 23 and 52 $\mathrm{km}$ from the city (forest habitat). Two pairs were collected in Paris location from two different parks and forest sites and in two different years, 2017 and 2018 (see table 1). They are subsequently called "Paris'17" for colonies collected in March 2017 and "Paris'18" for colonies collected in March 2018. Colonies from Lyon and Bordeaux were collected in February and March 2018. After collection, colonies were brought back to the laboratory and workers were counted. We discarded colonies with no queen or more than one queen ( 72 colonies) as well as colonies parasitized by cestodes $(9$ colonies, identified by the pale orange colour of workers). A total of 157 queenright colonies were used for the experiment and reared in foraging plastic boxes $(11.5 \times 11.5 \times 5.5 \mathrm{~cm})$ containing an artificial nest made of two microscope slides separated by a thin layer of plastic foam with hollow chambers. The top slide was covered with dark plastic to protect the colony from the light. Plastic boxes were kept in temperature-controlled chambers (reference CTS TP10/600) at $22^{\circ} \mathrm{C}$ from $7 \mathrm{pm}$ to $7 \mathrm{am}$ and $27^{\circ} \mathrm{C}$ from $7 \mathrm{am}$ to $7 \mathrm{pm}$. These stressful temperatures were chosen to speed up development and to amplify the effects of cadmium (57).

\section{Experimental design}

Our feeding treatment included two conditions: cadmium and control, applied to all locations and all pairs of habitats. In order to avoid any bias in colony size between control and cadmium conditions, we evenly assigned colonies to cadmium and control based on their colony size for each habitat within each 
location. Colonies were randomly distributed between the two chambers independently of their location, habitat and treatment. All original brood were removed from the colonies except for about 30 second instar larvae. When colonies had less than 30 second instar larvae, we left all of them in the colony. Newly laid eggs were removed every week to avoid the hatching of extra larvae. We fed colonies for 61 days every other day with a mixture of diluted honey and dried crickets containing $100 \mu \mathrm{g} / \mathrm{g}$ cadmium (cadmium condition) or not (control condition). This cadmium concentration corresponds to the $\mathrm{LC}_{50}$ (concentration at which half of the treated individuals die) of Spodoptera littoralis (M.A. Pottier personal communication). The mortality rate of the adult workers present in the colony from the beginning of the experiment (i.e. workers born in the field, subsequently called field workers) was computed based on the frequent removal of corpses and defined as the total number of dead field workers at the end of the experiment divided by the total number of field workers at the start of the experiment.

The experiment was performed over two different years: 2017 for Paris'17, and 2018 for Bordeaux, Lyon and Paris'18. For both years, colonies were acclimated for 14 days in laboratory before the experiment started. The experiment lasted for 61 days, so any larva that would have escaped the egg removal protocol and hatched could not have reached adulthood before the end of the experiment. The emerged workers (subsequently called lab workers) were identified based on their pale color (Temnothorax larvae do no spin a cocoon) and collected once they started to move. They were anesthetized by cooling down and stored in ethanol for subsequent morphological measurements. We computed the emergence rate of larvae as the ratio between the number of emerged adults (both workers and sexuals) and the initial number of larvae. The date of emergence was recorded in order to compute development duration for each lab worker, i.e. the duration from the second instar larva to the first movements of the newly emerged lab worker. Nine queens died during the experiment (one from Bordeaux-city-cadmium, one from Lyon-city-control, three from Paris'17-city-control, one from Paris'17-city-cadmium, two from Paris'17-forest-control and one from Paris'18-forest-cadmium). We excluded these colonies from the analyses, so 148 colonies were left in.

\section{Morphological measurements}


At the end of the experiment, the heads of lab and field workers were stuck on double-sided tape and photographed at a $x 5$ magnification under a stereomicroscope (Zeiss Discovery.V12) connected to a computer via a camera (Zeiss AxioCamICc). Head width was measured from eye to eye (just posterior to the eyes) with ImageJ (https://imagej.nih.gov/ij/; (58) and used as a proxy of body size (56).

\section{Statistical analyses}

We used R v1.1.383 (R Core Team, 2015) to conduct our statistical analyses. We tested for the effect of treatment (control, ie fed without cadmium, and cadmium, ie fed with cadmium), habitat (city or forest) and location (Paris'17, Paris'18, Bordeaux, Lyon), and their two level interactions on three dependent variables (mortality of field workers; emergence rate and size of lab workers). We considered the two collections in Paris as two independent locations (Paris'17 and Paris'18) as they were carried out during two different years and at two different pairs of sites. We also tested for the effect of two covariates (initial colony size and mean size of field workers) on each dependent variable to investigate the effects of these social parameters. To test for a buffering effect of colony size or field worker size, we included in the models the interaction between treatment and colony size or field worker size. For the two colonylevel dependent variables (mortality rate of field workers and emergence rate of lab workers), we used generalized linear models (GLMs). Because mortality and emergence rates were around 50\%, using a quasibinomial model was not better than using a Gaussian model with log-transformed data, and both models provided the same qualitative results. We therefore presented data from the Gaussian model for simplicity and because this allows to get AIC information. Regarding the individual-level dependent variable (size of lab workers), we used a linear mixed-effect model (lmer) with the package $n$ lme (59), including colony as a random effect. We visually checked the homogeneity of variance and normality of residuals. The minimal adequate model was chosen based on the AIC scores (stepmodel)(SI). The $P$ values for the explanatory variables and interactions were obtained by removing or adding the variable of interest from/to this minimal adequate model (60). $P$-values were obtained by comparing the model fitted with maximum likelihood method with and without the variable of interest using a log likelihood 
158

159

160

161

162

163

164

165

166

167

168

169

170

171

172

173

174

175

176

177

178

179

180

181

182

183

184

ratio test (anova). When necessary, we used lsmeans to compare means among the different levels of the explanatory variables.

\section{Results}

The 148 colonies produced a total of 1269 lab workers (922 for the control condition and 347 for the cadmium condition, Table 1), 215 males (176 for the control condition and 39 for the cadmium condition, Table 1), and no gynes in 61 days. Because only few males (39) emerged under cadmium condition, statistical power was lacking and we chose not to present results on male traits.

\section{Field workers}

Only nine queens died during the experiment. There was no differential queen mortality between control and cadmium conditions (Fisher's exact test, $P=0.49$ ) nor between city and forest colonies (Fisher's exact test, $P=0.32$ ).

Colony size (the number of field workers by colony) was only affected by the location $(F=4.90, P<$ 0.001), with larger colonies found in Paris'18 ( $P$-adjusted=0.041 for Paris'18-Bordeaux, $P$ adjusted $=0.014$ for Paris'18-Lyon and $P$-adjusted $=0.002$ for Paris'17-Paris'18). The size of field workers also differed among locations $(\mathrm{F}=17.58 ; P<0.001)$ with the bigger field workers found in Paris'17 and Paris'18 ( $P$-adjusted Paris'17-Paris'18=0.95, $P$-adjusted Paris'17-Bordeaux and Paris'18Bordeaux $<10^{-6}, P$-adjusted Paris' 17 - Lyon and Paris-18-Lyon $<10^{-3}$ ), and it was positively correlated with colony size $(\mathrm{F}=13.10, P<0.001$; slope estimate $=1.285 \mathrm{e}-04)$. However, there was no difference in the size of field workers $(\mathrm{p}=0.187, \mathrm{~F}=1.76)$ and in colony size $(P=0.87, \mathrm{~F}=0.024)$ between habitats.

At all locations, the mortality rate of field workers was significantly higher in cadmium condition than in control condition $\left(\mathrm{F}=115, P<10^{-16}\right)$ but the magnitude of the effect varied among locations (TreatmentLocation interaction, $P=0.00037, \mathrm{~F}=6.5$, Figure 1 , Table S2). Mortality rate significantly differed among locations $(\mathrm{F}=2.9, P=0.037)$ with a higher mortality rate in Lyon $(\mathrm{P}=0.07, \mathrm{t}=1.824$, figure 1$)$. Under the hypothesis that urban colonies resist better to stressors than forest colonies, we were expecting to find a differential effect of cadmium on mortality rate depending on habitat (Treatment: Habitat interaction). However we did not find this effect (Treatment: Habitat interaction, $P=0.91, \mathrm{~F}=0.1$ ) and 
there was no effect of habitat on mortality rate $(P=0.54, \mathrm{~F}=0.36)$. Regarding social parameters, colony size and size of field workers as well as their interactions with treatment did not affect mortality rates (Table S2).

\section{Laboratory workers}

In all locations, the emergence rate was significantly lower in cadmium condition than in control condition $\left(\mathrm{F}=104, P<10^{-16}\right.$, figure $\left.2 \mathrm{~A}\right)$ even though the magnitude of the effect differed significantly among locations (Treatment: Location interaction, $\mathrm{F}=2.7, P=0.045$, Table $\mathrm{S} 2$ ). The emergence rate significantly differed among locations $\left(\mathrm{F}=21, P<10^{-10}\right)$. Interestingly, when treated with cadmium, forest colonies experienced a stronger decrease in emergence rate than city colonies for all location (Treatment: Habitat interaction, $\mathrm{F}=4.22, P=0.04$, figure $2 \mathrm{~A}$, Table $\mathrm{S} 2$ ). This was associated with an increase in the number of larvae that apparently paused their development at early stages (15\% in control vs $30 \%$ in cadmium condition, $\mathrm{t}=3.76, \mathrm{df}=134, P=0.00024)$. Emergence rate in control condition was the same between city and forest habitats at each location (Paris'17: $\mathrm{t}=1.8, \mathrm{df}=16, P=0.08$; Lyon: $\mathrm{t}=-0.07, \mathrm{df}=5.9$, $P=0.9$; Paris'18: $\mathrm{t}=-0.44, \mathrm{df}=18.9, P=0.65)$ except for Bordeaux $(\mathrm{t}=-2.99, \mathrm{df}=10.3, P=0.01)$, so the observed Treatment: Habitat interaction was not caused by an initial differential emergence rate between forest and city colonies when exposed to a stressful temperature. The only social parameters affecting the emergence rate was the mean size of field worker (Table S2), with colonies containing larger field workers having lower emergence rate $(\mathrm{F}=9.7, P=0.0022$, slope estimate $=-2.4)$ whatever the treatment (no significant interaction treatment and size of field workers $(P=0.62, F=0.24)$.

Colonies treated with cadmium produced significantly smaller lab workers in all locations but as previously, the effect significantly differed in magnitude among locations (Treatment: Location interaction, $\mathrm{X}_{3}=9.87, P=0.0197$, Figure $2 \mathrm{~B}, P<10^{-2}$, Table S3). Interestingly, this decrease in the size of lab workers was stronger in forest colonies than in city colonies for all location (Treatment: Habitat interaction, $\mathrm{X}_{1}=5.03, P=0.02485$, table $\mathrm{S} 3$, Figure $2 \mathrm{~B}$ ). The size of lab workers under control condition did not differ between the two types of habitats for all location (Paris'17: $\mathrm{t}=1, P=0.29$, Lyon: $\mathrm{t}=0.8$, 
$P=0.4$, Paris'18: $\mathrm{t}=-1.7, P=0.09)$ except for Bordeaux $(\mathrm{t}=-3.2, P=0.002)$, so the observed Treatment: Habitat interaction was not caused by an initial difference in the size of lab workers between forest and city colonies when exposed to a stressful temperature. Regarding social parameters, only colony size affected significantly and positively the size of lab workers $\left(X_{1}=12.52, P=0.00040\right.$, slope estimate $=1.7 \mathrm{e}-04$ ) whatever the treatment (no significant interaction between treatment and colony size) (Table S3 to see all statistical results).

\section{Discussion}

The aim of our study was to assess whether urban colonies of the small acorn ant Temnothorax nylanderi are more resistant to a trace metal than forest colonies. We exposed them to food with a very high cadmium concentration. As expected, this caused an increase in adult mortality rates, and a decrease in size and emergence rate of lab workers relative to the control condition, confirming that cadmium condition has a negative effect on life history traits in this species as found in other insects $(61,62)$. More interestingly, our experiment showed that city colonies were less affected by cadmium than the forest ones and this was observed in the four city/forest pairs studied, strongly suggesting a general effect of urbanization in term of cadmium resistance. Whether this effect of urbanization could be considered as an adaptive response is discussed below.

Different hypotheses could explain the lower vulnerability of city colonies to cadmium. First, because urban soils often contain more cadmium than non-urban soils (on average, $2.45 \mathrm{mg} / \mathrm{kg}$ for urban wood soil in Paris, and $0.3 \mathrm{mg} / \mathrm{kg}$ in rural wood soils of Ile-de-France (35)), we can hypothesize that urban colonies have acquired a resistance to cadmium following exposure. Such adaptation has already been documented in the collembola Orchesella cincta, where individuals from populations of heavily cadmium-contaminated disused mining sites are more resistant to cadmium (63). Second, the better resistance to cadmium of city colonies observed in our experiment could reflect a general resistance to other trace elements such as arsenic, zinc, lead or mercury that could be found at a higher concentration in urban leaf litter because of intense industrial activity and proximity with traffic. Accordingly, urban 
ants may have evolved general detoxification systems that can cope with various trace elements. Third, more generally, the lower sensitivity to cadmium of city colonies could reflect a better tolerance to various stressors. Indeed, it is important to remind that our rearing temperature was stressful for ants (22-27 ${ }^{\circ} \mathrm{C}$ as opposed to the typical $15-20{ }^{\circ} \mathrm{C}$ experienced in nature, (56)). Because of the Urban Heat Island effect, populations living in urban centers frequently experience higher temperature than their non-urban counterparts and could therefore be less stressed by heat (64) allowing them to resist better to cadmium. City colonies did not perform better than forest colonies under control conditions, but this may be due to the ability of forest colonies to buffer stressors. When exposed to several stressing factors (heat + cadmium), forest colonies may however collapse whereas urban colonies would resist. Interestingly, studies performed on European black birds reared under common garden experiments showed that urban populations have a lower stress response to human handling than their rural counterparts (19), suggesting that urban populations can evolve a general tolerance to stressors. These conclusions should be confirmed by further experiments to assess whether the observed lower sensitivity to cadmium of city colonies in $T$. nylanderi is due to a general resistance to stress or to a more efficient detoxification system.

An unexpected effect of cadmium was the increased frequency of larvae stopping their development. These larvae did not grow over the entire course of the experiment, but they still looked alive and were kept in the nest with the rest of the brood and cared for by workers, unlike dead larvae that were typically discarded outside. In insects, environmental factors such as cold temperature, can induce a pause in development (65). In ants, diapause seems to be endogenous, even if external factors such as photoperiod and temperature can secondarily affect its occurrence and duration (66). However diapause can be induced by other non-seasonal (thus unpredictable) environmental factors, such as trace metals in adult earthworms or hypoxia in C. elegans embryos $(67,68)$. Diapausing individuals usually survive longer in response to a stress, for example flesh-fly larvae exposed to anoxic conditions (69). Thus, diapause can be interpreted as a stress-avoidance mechanism(67). The higher proportion of paused T. nylanderi larvae under cadmium condition may be a general defense mechanism to face a wide range of stressors. It is unknown whether paused larvae can resume development or are just barely surviving and are doomed 
to death. This and the potential impact of paused development on the life history traits of workers that would manage to resume development deserves further investigation.

The differential response to cadmium between urban and non-urban colonies of $T$. nylanderi could have genetic or environmental determination. In some hexapodes, populations that are tolerant to heavy metal have duplicated metallothionein genes (Drosophila melanogaster, (70)) or an increased expression of a single metallothionein gene (Orchesella cincta, (71)). A recent genomic analysis (Rad-seq) based on our T. nylanderi colonies revealed a lack of genetic differentiation between habitats (Khimoun et al, submitted). However, the authors found that 19 loci are under divergent selection between urban and non-urban populations, but none of them corresponding to metallothionein genes. Interestingly, two of these loci (one from the Lyon pair of populations and one from the Bordeaux pair of populations) code for kinase $\mathrm{C}$ proteins involved in signalization pathways (72). Two other loci (both from the Lyon pair of populations) code for a protein involved in mRNA processing and for a membrane protein. These results support the idea that, in spite of a high gene flow among populations, adaptive genetic differentiation can occur between urban and forest populations. Similarly, Schrader et al (73) found that the invasive ant Cardiocondyla obscurior could rapidly adapt to environmental changes because of transposable elements (TE) that generate genetic diversity through transpositions. Given that stressors could trigger transposition events (74), it would be interesting to test whether TE could trigger genetic adaptation in urban populations exposed to various stressors in T. nylanderi. Phenotypic differences found after a single laboratory generation could also result from maternal effects and/or epigenetic effects. For example, queens experiencing stressful conditions like pollution may undergo epigenetic modifications of their genome that would be transmitted and help workers to face stressors. In that case, urban queens could resist better to cadmium; however we did not find differential queen mortality between city and forest colonies. This may be due to a lack of statistical power as very few queens died over the experiment. Moreover, there was no differential queen mortality between control and cadmium colonies despite a strong differential worker mortality. Some studies suggested that workers act as a filter, limiting queen exposure to toxic compounds such as cadmium (75). It is possible that queens are 
291

292

293

294

295

296

297

298

299

300

301

302

303

304

305

306

307

308

309

310

311

312

313

314

315

316

exposed to pollution during colony foundation only, and not after, limiting the potential involvement of maternal effects.

In social groups, the phenotype of an individual is also determined by the surrounding social environment. The social environment includes colony size (number of individuals), the phenotype of other individuals (caste, size, morphology, physiology, behaviour), the proportion of individual types, and complex emerging group properties including communication. In this study, we tested for a potential buffering effect of colony size and size of field workers on the response to cadmium. We found two effects of social factors on the phenotype of lab workers but they were similar with and without cadmium. 1/ Larger colonies produced larger lab workers, a typical phenomenon in ants (56,76). 2/ Colonies with larger field workers had a lower emergence rate, which may be due to the longer development duration of large workers that were then exposed to cadmium for longer. In contrast, in bees, larger colonies were found to be more resistant to cadmium $(47,48)$. Even though we did not detect any effect of the social environment on colony sensitivity to cadmium, workers from urban colonies could still be more used to polluted food or stressors. Workers could change their behavior when facing cadmium, either through direct induction by cadmium or indirectly through the higher mortality triggered by cadmium. The relative contribution of intrinsic factors within larvae and social factors (i.e. nestmates that limit or enhance environmental variations experienced by larvae) deserves further investigation through cross-fostering experiments. Social life could deeply impact the ability of ants to face environmental changes. On one hand, it may help species to cope with environmental changes to an extent that cannot be achieved by solitary species. The social filtering of the environment can for instance protect the brood from temperature fluctuations, drought, starvation or pathogens. On the other hand, consequences of social life such as extreme task-specialization or obligatory collective behavior may make social species more vulnerable to environmental changes $(77,78)$. Because of the ecologic and economic values of social species $(46,75)$ it is crucial to understand how they react to environmental changes.

\section{Conclusion}


317 Our study provides a unique example of replicated common garden experiment highlighting a better

318 resistance to cadmium in urban colonies. The plastic response is convergent across all four urban/forest

319 pairs tested. This differential resistance can be genetically determined, due to the social environment, or

320 a combination of both. The social factors that we assessed had no effect on colony resistance to

321 cadmium, in contrast with what was found in bees. To our knowledge, the role of sociality in the

322 adaptation to environmental changes has barely been investigated. The relative contribution of

323 individual and social factors to the final adult phenotype could be assessed through cross fostering

324 experiments.

\section{Figures Legend}

Figure 1: Boxplot of the mortality rate of field workers by habitat, location and treatment.

327 Colonies fed with cadmium are in red, colonies fed with control are in blue. Boxes show median, quartiles and extreme values. Statistics are presented in Table S2.

Figure 2: Boxplot of worker traits by habitat, location and treatment. Colonies fed with cadmium are in red, colonies fed with control are in blue. (A) Emergence rate of lab workers. (B) Head width of lab workers (mm). Boxes show median, quartiles and extreme values

Tables

\begin{tabular}{|c|c|c|c|c|c|}
\hline & & Control & Cadmium & Site & GPS \\
\hline \multirow{6}{*}{ Paris'17 } & City & 13 & 14 & Jardin & $48^{\circ} 50^{\prime} 59.684^{\prime \prime} \mathrm{N}$ \\
\hline & & $247 \mathrm{~W}, 21 \mathrm{M}$ & $206 \mathrm{~W}, 8 \mathrm{M}$ & Ecologique & $2^{\circ} 21^{\prime} 40.385^{\prime \prime} \mathrm{E}$ \\
\hline & \multirow[t]{2}{*}{ Forest } & 13 & 13 & Fontainebleau & $48^{\circ} 26^{\prime} 2.595^{\prime \prime N}$ \\
\hline & & $213 \mathrm{~W}, 6 \mathrm{M}$ & $87 \mathrm{~W}, 1 \mathrm{M}$ & & $2^{\circ} 43^{\prime} 52.842^{\prime \prime} \mathrm{E}$ \\
\hline & \multirow[t]{2}{*}{ City } & 7 & 7 & Jardin public & $44^{\circ} 51^{\prime} 16.9^{\prime \prime} \mathrm{N}$ \\
\hline & & $39 \mathrm{~W}, 12 \mathrm{M}$ & $12 \mathrm{~W}, 1 \mathrm{M}$ & & $0^{\circ} 35^{\prime} 16.5^{\prime \prime} \mathrm{W}$ \\
\hline
\end{tabular}




\begin{tabular}{|c|c|c|c|c|c|}
\hline Bordeaux & Forest & 12 & 11 & Monfaucon & $44^{\circ} 52^{\prime 2} 23.6^{\prime \prime N}$ \\
\hline & & $130 \mathrm{~W}, 29 \mathrm{M}$ & $11 \mathrm{~W}, 11 \mathrm{M}$ & & $0^{\circ} 08^{\prime} 14.7^{\prime \prime} \mathrm{W}$ \\
\hline \multirow{4}{*}{ Lyon } & City & 4 & 5 & Tête d'Or & $45^{\circ} 46^{\prime} 44.2^{\prime \prime N}$ \\
\hline & & $18 \mathrm{~W}, 22 \mathrm{M}$ & $10 \mathrm{~W}, 1 \mathrm{M}$ & & $4^{\circ} 52^{\prime} 54.3^{\prime \prime E}$ \\
\hline & Forest & 4 & 4 & Arandon & $45^{\circ} 43^{\prime} 07.5^{\prime \prime} \mathrm{N}$ \\
\hline & & $28 \mathrm{~W}, 4 \mathrm{M}$ & $7 \mathrm{~W}, 3 \mathrm{M}$ & & $5^{\circ} 26^{\prime} 44.5^{\prime \prime} \mathrm{E}$ \\
\hline \multirow{4}{*}{ Paris'18 } & City & 10 & 11 & Buttes & $48^{\circ} 52^{\prime} 47.1^{\prime \prime N}$ \\
\hline & & $107 \mathrm{~W}, 64 \mathrm{M}$ & $7 \mathrm{~W}, 7 \mathrm{M}$ & Chaumont & $2^{\circ} 23^{\prime} 45.6^{\prime \prime E}$ \\
\hline & Forest & 10 & 10 & Chantilly & $49^{\circ} 10^{\prime} 59.8^{\prime \prime N} \mathrm{~N}$ \\
\hline & & $140 \mathrm{~W}, 23 \mathrm{M}$ & $7 \mathrm{~W}, 2 \mathrm{M}$ & & $2^{\circ} 28^{\prime} 43.6^{\prime \prime E}$ \\
\hline
\end{tabular}

Table 1: Number of Temnothorax nylanderi colonies used and number of workers (W) and males (M) collected for each location, treatment and habitat type.

\section{References}

1. Seto KC, Güneralp B, Hutyra LR. Global forecasts of urban expansion to 2030 and direct impacts on biodiversity and carbon pools. Proc Natl Acad Sci. 2 oct 2012;109(40):16083-8.

2. Pickett STA, Cadenasso ML, Grove JM, Nilon CH, Pouyat RV, Zipperer WC, et al. Urban Ecological Systems: Linking Terrestrial Ecological, Physical, and Socioeconomic Components of Metropolitan Areas. Annu Rev Ecol Syst. 2001;32(1):127-57.

3. Bornstein RD. Observations of the Urban Heat Island Effect in New York City. J Appl Meteorol. 1 août 1968;7(4):575-82.

4. McDonnell MJ, Pickett STA, Groffman P, Bohlen P, Pouyat RV, Zipperer WC, et al. Ecosystem processes along an urban-to-rural gradient. Urban Ecosyst. 1 mars 1997;1(1):21-36.

5. Buczkowski G, Richmond DS. The Effect of Urbanization on Ant Abundance and Diversity: A Temporal Examination of Factors Affecting Biodiversity. PLOS ONE. 2 août 2012;7(8):e41729.

6. McDonnell MJ, Hahs AK. Adaptation and Adaptedness of Organisms to Urban Environments. Annu Rev Ecol Evol Syst. 2015;46(1):261-80. 
7. Weller B, Ganzhorn JU. Carabid beetle community composition, body size, and fluctuating asymmetry along an urban-rural gradient. Basic Appl Ecol. janv 2004;5(2):193-201.

8. Niemelä J, Kotze DJ, Venn S, Penev L, Stoyanov I, Spence J, et al. Carabid beetle assemblages (Coleoptera, Carabidae) across urban-rural gradients: an international comparison. Landsc Ecol. 1 juill 2002;17(5):387-401.

9. Banaszak-Cibicka W, Żmihorski M. Wild bees along an urban gradient: winners and losers. J Insect Conserv. 1 juin 2012;16(3):331-43.

10. Blair RB. Birds and Butterflies Along Urban Gradients in Two Ecoregions of the United States: Is Urbanization Creating a Homogeneous Fauna? In: Lockwood JL, McKinney ML, éditeurs. Biotic Homogenization [Internet]. Boston, MA: Springer US; 2001 [cité 15 janv 2019]. p. 33-56. Disponible sur: https://doi.org/10.1007/978-1-4615-1261-5_3

11. Clergeau P, Savard J-PL, Mennechez G, Falardeau G. Bird Abundance and Diversity along an Urban-Rural Gradient: A Comparative Study between Two Cities on Different Continents. The Condor. 1998;100(3):413-25.

12. Germaine SS, Wakeling BF. Lizard species distributions and habitat occupation along an urban gradient in Tucson, Arizona, USA. Biol Conserv. 1 févr 2001;97(2):229-37.

13. Alexandre CV, Esteves KE, de Moura e Mello MAM. Analysis of fish communities along a rural-urban gradient in a neotropical stream (Piracicaba River Basin, São Paulo, Brazil). Hydrobiologia. 1 mars 2010;641(1):97-114.

14. Pillsbury FC, Miller JR. Habitat and Landscape Characteristics Underlying Anuran Community Structure Along an Urban-Rural Gradient. Ecol Appl. 2008;18(5):1107-18.

15. Cheptou P-O, Carrue O, Rouifed S, Cantarel A. Rapid evolution of seed dispersal in an urban environment in the weed Crepis sancta. Proc Natl Acad Sci. 11 mars 2008;105(10):3796-9.

16. McKinney ML. Effects of urbanization on species richness: A review of plants and animals. Urban Ecosyst. 1 juin 2008;11(2):161-76.

17. Mendes S, Colino-Rabanal VJ, Peris SJ. Bird song variations along an urban gradient: The case of the European blackbird (Turdus merula). Landsc Urban Plan. 30 janv 2011;99(1):51-7.

18. Evans KL, Newton J, Gaston KJ, Sharp SP, McGowan A, Hatchwell BJ. Colonisation of urban environments is associated with reduced migratory behaviour, facilitating divergence from ancestral populations. Oikos. 2012;121(4):634-40.

19. Partecke J, Schwabl I, Gwinner E. Stress and the City: Urbanization and Its Effects on the Stress Physiology in European Blackbirds. Ecology. 2006;87(8):1945-52.

20. Partecke Jesko, Van't Hof Thomas, Gwinner Eberhard. Differences in the timing of reproduction between urban and forest European blackbirds (Turdus merula): result of phenotypic flexibility or genetic differences? Proc R Soc Lond B Biol Sci. 7 oct 2004;271(1552):1995-2001.

21. Chick LD, Strickler SA, Perez A, Martin RA, Diamond SE. Urban heat islands advance the timing of reproduction in a social insect. J Therm Biol. 1 févr 2019;80:119-25.

22. Dominoni D. M., Helm B., Lehmann M., Dowse H. B., Partecke J. Clocks for the city: circadian differences between forest and city songbirds. Proc R Soc B Biol Sci. 22 juill 2013;280(1763):20130593. 
23. Bradley CA, Altizer S. Urbanization and the ecology of wildlife diseases. Trends Ecol Evol. 1 févr 2007;22(2):95-102.

24. Liker A, Papp Z, Bókony V, Lendvai ÁZ. Lean birds in the city: body size and condition of house sparrows along the urbanization gradient. J Anim Ecol. 2008;77(4):789-95.

25. Johnson Marc T. J., Prashad Cindy M., Lavoignat Mélanie, Saini Hargurdeep S. Contrasting the effects of natural selection, genetic drift and gene flow on urban evolution in white clover (Trifolium repens). Proc R Soc B Biol Sci. 25 juill 2018;285(1883):20181019.

26. Lu P, Yu Q, Liu J, Lee X. Advance of tree-flowering dates in response to urban climate change. Agric For Meteorol. 29 août 2006;138(1):120-31.

27. Chamberlain DE, Cannon AR, Toms MP, Leech DI, Hatchwell BJ, Gaston KJ. Avian productivity in urban landscapes: a review and meta-analysis. Ibis. 2009;151(1):1-18.

28. Leong M, Ponisio LC, Kremen C, Thorp RW, Roderick GK. Temporal dynamics influenced by global change: bee community phenology in urban, agricultural, and natural landscapes. Glob Change Biol. 2016;22(3):1046-53.

29. Isaksson C. Pollution and Its Impact on Wild Animals: A Meta-Analysis on Oxidative Stress. EcoHealth. 1 sept 2010;7(3):342-50.

30. Scales J, Hyman J, Hughes M. Behavioral Syndromes Break Down in Urban Song Sparrow Populations. Ethology. 2011;117(10):887-95.

31. Hof AE van't, Campagne P, Rigden DJ, Yung CJ, Lingley J, Quail MA, et al. The industrial melanism mutation in British peppered moths is a transposable element. Nature. juin 2016;534(7605):102-5.

32. Slabbekoorn H, den Boer-Visser A. Cities Change the Songs of Birds. Curr Biol. 5 déc 2006;16(23):2326-31.

33. Lazić MM, Carretero MA, Crnobrnja-Isailović J, Kaliontzopoulou A. Effects of Environmental Disturbance on Phenotypic Variation: An Integrated Assessment of Canalization, Developmental Stability, Modularity, and Allometry in Lizard Head Shape. Am Nat. 1 janv 2015;185(1):44-58.

34. Lowe EC, Wilder SM, Hochuli DF. Urbanisation at Multiple Scales Is Associated with Larger Size and Higher Fecundity of an Orb-Weaving Spider. PLOS ONE. 20 août 2014;9(8):e105480.

35. Foti L, Dubs F, Gignoux J, Lata J-C, Lerch TZ, Mathieu J, et al. Trace element concentrations along a gradient of urban pressure in forest and lawn soils of the Paris region (France). Sci Total Environ. 15 nov 2017;598:938-48.

36. Ieradi LA, Cristaldi M, Mascanzoni D, Cardarelli E, Grossi R, Campanella L. Genetic damage in urban mice exposed to traffic pollution. Environ Pollut. 1 janv 1996;92(3):323-8.

37. Guxens M, Sunyer J. A review of epidemiological studies on neuropsychological effects of air pollution. Swiss Med Wkly. 2012;141:w13322.

38. Stroiński A. Some physiological and biochemical aspects of plant resistance to cadmium effect. I. Antioxidative system. Acta Physiol Plant. 1 juin 1999;21(2):175-88.

39. Gomot A. Toxic Effects of Cadmium on Reproduction, Development, and Hatching in the Freshwater SnailLymnaea stagnalisfor Water Quality Monitoring. Ecotoxicol Environ Saf. 1 nov 1998;41(3):288-97. 
40. Cervera A, Maymó AC, Sendra M, Martínez-Pardo R, Garcerá MD. Cadmium effects on development and reproduction of Oncopeltus fasciatus (Heteroptera: Lygaeidae). J Insect Physiol. août 2004;50(8):737-49.

41. den Besten PJ, Herwig HJ, Zandee DI, Voogt PA. Effects of cadmium and PCBs on reproduction of the sea star Asterias rubens: Aberrations in the early development. Ecotoxicol Environ Saf. 1 oct 1989;18(2):173-80.

42. Demenesku J, Mirkov I, Ninkov M, Popov Aleksandrov A, Zolotarevski L, Kataranovski D, et al. Acute cadmium administration to rats exerts both immunosuppressive and proinflammatory effects in spleen. Toxicology. 4 déc 2014;326:96-108.

43. Schultz TR. In search of ant ancestors. Proc Natl Acad Sci U S A. 19 déc 2000;97(26):14028-9.

44. Farji-Brener AG, Lescano N, Ghermandi L. Ecological engineering by a native leaf-cutting ant increases the performance of exotic plant species. Oecologia. 1 mai 2010;163(1):163-9.

45. Sanders D, Veen FJF van. Ecosystem engineering and predation: the multi-trophic impact of two ant species. J Anim Ecol. 2011;80(3):569-76.

46. Philpott SM, Armbrecht I. Biodiversity in tropical agroforests and the ecological role of ants and ant diversity in predatory function. Ecol Entomol. 2006;31(4):369-77.

47. Rundlöf M, Andersson GKS, Bommarco R, Fries I, Hederström V, Herbertsson L, et al. Seed coating with a neonicotinoid insecticide negatively affects wild bees. Nature. 7 mai 2015;521(7550):77-80.

48. Crall JD, de Bivort BL, Dey B, Ford Versypt AN. Social Buffering of Pesticides in Bumblebees: Agent-Based Modeling of the Effects of Colony Size and Neonicotinoid Exposure on Behavior Within Nests. Front Ecol Evol [Internet]. 4 mars 2019 [cité 15 mai 2019];7. Disponible sur: https://www.frontiersin.org/article/10.3389/fevo.2019.00051/full

49. Modlmeier AP, Foitzik S, Scharf I. Starvation endurance in the ant Temnothorax nylanderi depends on group size, body size and access to larvae. Physiol Entomol. 2013;38(1):89-94.

50. Scharf I, Modlmeier AP, Beros S, Foitzik S. Ant Societies Buffer Individual-Level Effects of Parasite Infections. Am Nat. 1 nov 2012;180(5):671-83.

51. Lessard J-P, Buddle CM. The effects of urbanization on ant assemblages (Hymenoptera: Formicidae) associated with the Molson Nature Reserve, Quebec. Can Entomol. avr 2005;137(2):215-25.

52. Thompson B, McLachlan S. The effects of urbanization on ant communities and myrmecochory in Manitoba, Canada. Urban Ecosyst. 1 mars 2007;10(1):43-52.

53. McIntyre NE. Ecology of Urban Arthropods: a Review and a Call to Action. Ann Entomol Soc Am. 1 juill 2000;93(4):825-35.

54. Buczkowski G. Extreme life history plasticity and the evolution of invasive characteristics in a native ant. Biol Invasions. 1 sept 2010;12(9):3343-9.

55. Grześ IM. Ants and heavy metal pollution - A review. Eur J Soil Biol. 1 nov 2010;46(6):350-5.

56. Molet M, Péronnet R, Couette S, Canovas C, Doums C. Effect of temperature and social environment on worker size in the ant Temnothorax nylanderi. J Therm Biol. 1 juill 2017;67:22-9. 
57. Abdel-Lateif HM, Donker MH, Straalen NMV. Interaction between temperature and cadmium toxicity in the isopod Porcellio scaber. Funct Ecol. 1998;12(4):521-7.

58. Abràmoff MD, Magalhães PJ, Ram SJ. Image processing with ImageJ. Biophotonics Int. 2004;11(7):36-42.

59. Pinheiro J, Bates D, DebRoy S, Sarkar D, Team RC. nlme: Linear and Nonlinear Mixed Effects Models, 2015. R Package Version. 2016;3:103.

60. Zuur A, Ieno EN, Walker N, Saveliev AA, Smith GM. Mixed effects models and extensions in ecology with R. Springer Science \& Business Media; 2009.

61. Malakar C, Ganguly A, Haldar P. Influence of cadmium on growth, survival and clutch size of a common Indian short horned grasshopper, Oxya fuscovittata. Am J Toxicol Sci. 2009;1:32-6.

62. Mirčić D, Janković-Tomanić M, Nenadović V, Franeta F, Lazarević J. The effects of cadmium on the life history traits of Lymantria dispar L. Arch Biol Sci. 2010;62(4):1013-20.

63. Roelofs D, Janssens TKS, Timmermans MJTN, Nota B, Mariën J, Bochdanovits Z, et al. Adaptive differences in gene expression associated with heavy metal tolerance in the soil arthropod Orchesella cincta. Mol Ecol. 2009;18(15):3227-39.

64. Diamond SE, Chick L, Perez A, Strickler SA, Martin RA. Rapid evolution of ant thermal tolerance across an urban-rural temperature cline. Biol J Linn Soc. 1 juin 2017;121(2):248-57.

65. Andrewartha HG. Diapause in Relation to the Ecology of Insects. Biol Rev. 1952;27(1):50-107.

66. Kipyatkov VE, Lopatina EB. Temperature and photoperiodic control of diapase induction in the ant Lepisiota semenovi (Hymenoptera, formicidae) from Turkmenistan. J Evol Biochem Physiol. 1 avr 2009;45(2):238-45.

67. Morgan JE, Morgan AJ. Seasonal changes in the tissue-metal $(\mathrm{Cd}, \mathrm{Zn}$ and $\mathrm{Pb})$ concentrations in two ecophysiologically dissimilar earthworm species: pollution-monitoring implications. Environ Pollut. 1 janv 1993;82(1):1-7.

68. Miller DL, Roth MB. C. Elegans Are Protected from Lethal Hypoxia by an Embryonic Diapause. Curr Biol. 28 juill 2009;19(14):1233-7.

69. Kukal O, Denlinger DL, Lee RE. Developmental and metabolic changes induced by anoxia in diapausing and non-diapausing flesh fly pupae. J Comp Physiol B. 1 nov 1991;160(6):683-9.

70. Maroni G, Wise J, Young JE, Otto E. Metallothionein Gene Duplications and Metal Tolerance in Natural Populations of Drosophila melanogaster. Genetics. 1 déc 1987;117(4):739-44.

71. Roelofs D, Overhein L, Boer ME de, Janssens TKS, Straalen NM van. Additive genetic variation of transcriptional regulation: metallothionein expression in the soil insect Orchesella cincta. Heredity. janv 2006;96(1):85.

72. Thévenod F. Cadmium and cellular signaling cascades: To be or not to be? Toxicol Appl Pharmacol. 1 août 2009;238(3):221-39.

73. Schrader L, Kim JW, Ence D, Zimin A, Klein A, Wyschetzki K, et al. Transposable element islands facilitate adaptation to novel environments in an invasive species. Nat Commun. 16 déc 2014;5:5495. 
74. Mirouze M, Paszkowski J. Epigenetic contribution to stress adaptation in plants. Curr Opin Plant Biol. 1 juin 2011;14(3):267-74.

75. Klatt Björn K., Holzschuh Andrea, Westphal Catrin, Clough Yann, Smit Inga, Pawelzik Elke, et al. Bee pollination improves crop quality, shelf life and commercial value. Proc R Soc B Biol Sci. 22 janv 2014;281(1775):20132440.

76. Porter SD, Tschinkel WR. Fire Ant Polymorphism (Hymenoptera: Formicidae): Factors Affecting Worker Size. Ann Entomol Soc Am. 1 mai 1985;78(3):381-6.

77. Chapman RE, Bourke AFG. The influence of sociality on the conservation biology of social insects. Ecol Lett. 2001;4(6):650-62.

78. Luque GM, Giraud T, Courchamp F. Allee effects in ants. J Anim Ecol. 2013;82(5):956-65. 


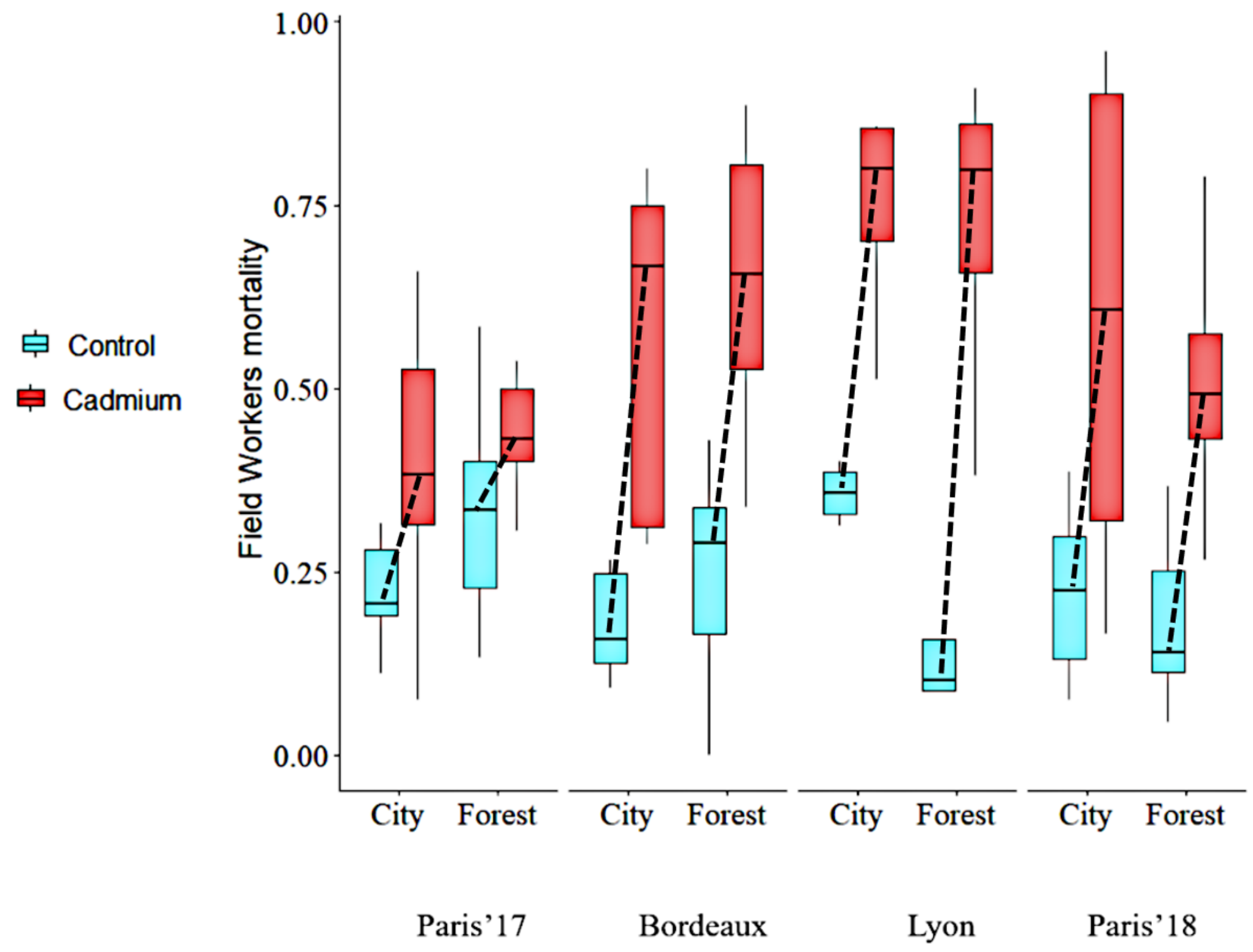




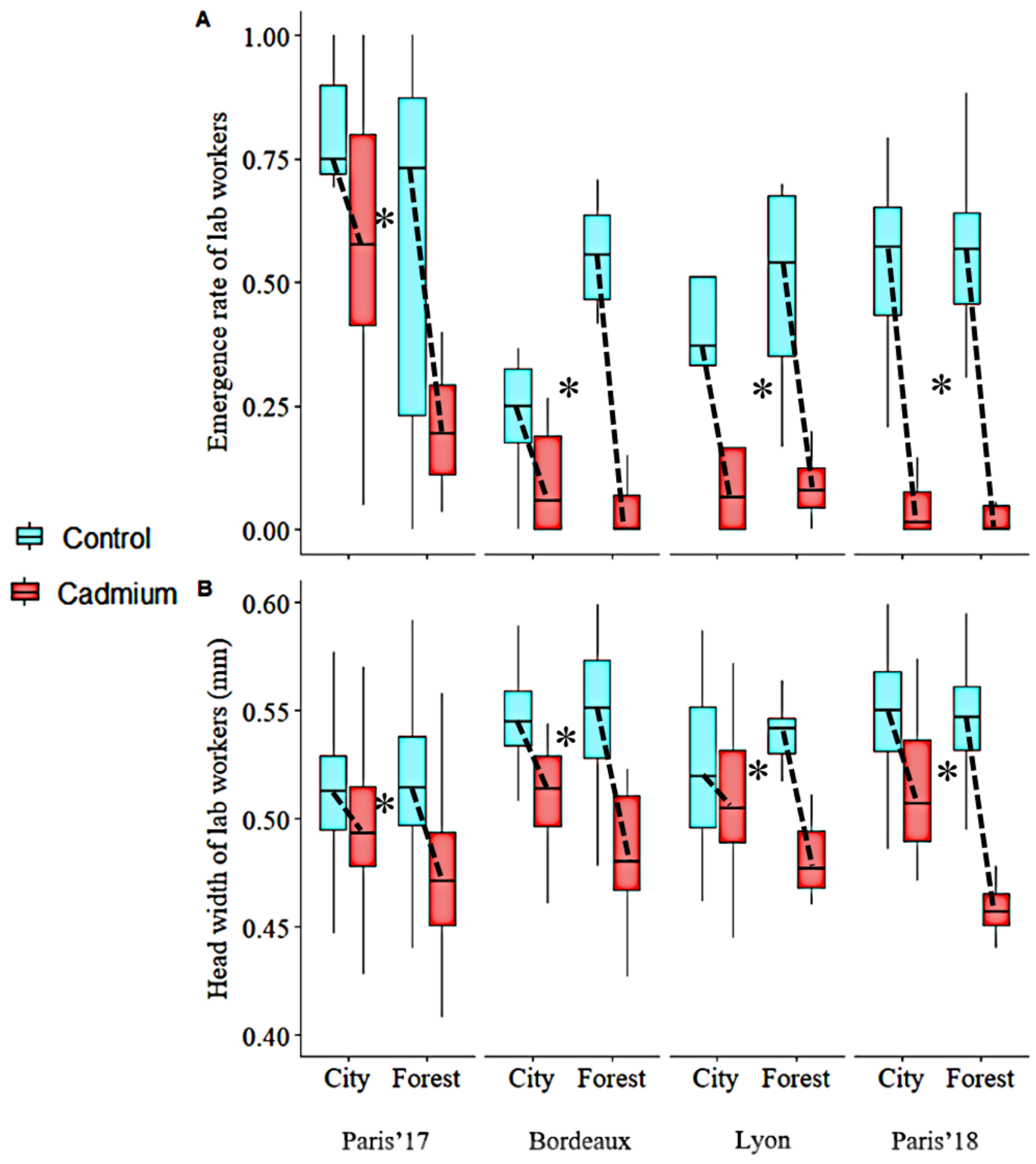


Urban colonies are more resistant to a trace metal than their forest counterparts in the ant Temnothorax nylanderi L. Jacquier ${ }^{1 *}$, C. Doums ${ }^{2}$, A. Four-Chaboussant ${ }^{3}$, R. Peronnet $^{1}$, C. Tirard $^{1}$, M. Molet ${ }^{1}$ Journal: Urban Ecosystem

${ }^{1}$ Institute of Ecology and Environmental Sciences of Paris, Sorbonne Université, Paris, France

${ }^{2}$ EPHE, PSL Paris, France

${ }^{3}$ Master EBE, Sorbonne Université, Paris, France

*Corresponding author: lauren.jacquier@gmail.com

\section{Supplementary Information}

\section{Statistical models}

For each dependent variable, we built the following complete model:

Dependent variable $\sim$ Treatment:Habitat + Treatment:Location + Treatment + Habitat + Location + Colony size:Treatment + Mean field worker size:Treatment + Colony size + Mean field worker size Treatment $(+$ random Colony effect).

We then chose the minimal adequate model based on AIC scores. Finally, we tested the effect of each factor as follows: (1) Colony size:Treatment; (2) Mean field worker size:Treatment (3) Colony size; (4) Mean field worker size; (5) Treatment:Habitat; (6) Treatment:Location; (7) Treatment; (8) Habitat and (9) Location. When the Treatment:Habitat or the Treatment:Location interaction was significant, we used lsmeans to estimate the effect of one factor depending on the level of the other.

\begin{tabular}{lll}
\hline & Colony size & Size of field workers \\
\hline Colony size & NA & $F_{l}=13.10$ \\
& & 0.00042 \\
Treatment : Habitat & $F_{l}=2.13$ & $F_{l}=1.93$ \\
& 0.15 & 0.17 \\
Treatment : Location & $F_{3}=0.61$ & $F_{3}=0.93$ \\
\hline
\end{tabular}




\begin{tabular}{lll}
\hline & 0.61 & 0.43 \\
Treatment & $F_{1}=0$ & $F_{1}=1.49$ \\
& 0.99 & 0.22 \\
& $F_{l}=0.02$ & $F_{l}=1.76$ \\
Habitat & 0.8754 & 0.187 \\
& $F_{3}=4.89$ & $F_{3}=17.6$ \\
& $2.85 \times 10^{-3}$ & $<10^{-6}$ \\
Location & & \\
\hline Table S1: Effect of the different factors and their interactions on colony size (number of field \\
workers) and size of field workers. Fisher scores and associated p-values are from ANOVAs between
\end{tabular}

Mortality rate of

Emergence rate of

field workers

lab workers

\begin{tabular}{|c|c|c|}
\hline \multirow[t]{2}{*}{ Colony size } & $F_{1}=1.8$ & $F_{1}=0.3$ \\
\hline & 0.17 & 0.58 \\
\hline \multirow[t]{2}{*}{ Size of field workers } & $F_{1}=0.8$ & $F_{1}=8.8$ \\
\hline & 0.37 & 0.0034 \\
\hline Colony size : & $F_{l}=0.072$ & $F_{1}=0.74$ \\
\hline Treatment & 0.93 & 0.38 \\
\hline Size of field & $F=0.023$ & $F-1=0.24$ \\
\hline workers :Treatment & 0.87 & 0.62 \\
\hline \multirow[t]{2}{*}{ Treatment : Habitat } & $F_{l}=0.01$ & $F_{1}=4.22$ \\
\hline & 0.91 & 0.041 \\
\hline \multirow[t]{2}{*}{ Treatment : Location } & $F_{3}=6.5$ & $F_{3}=2.87$ \\
\hline & $<10^{-3}$ & 0.038 \\
\hline \multirow[t]{2}{*}{ Treatment } & $F_{1}=115$ & $F_{1}=104$ \\
\hline & $<10^{-16}$ & $<10^{-16}$ \\
\hline Habitat & $F_{1}=0.36$ & $F_{1}=5.8$ \\
\hline
\end{tabular}




\begin{tabular}{|c|c|c|c|c|c|c|c|c|}
\hline & 0.54 & & & & 0.017 & & & \\
\hline \multirow[t]{2}{*}{ Location } & $F_{3}=2.9$ & & & & \multicolumn{4}{|l|}{$F_{3}=21.3$} \\
\hline & 0.035 & & & & \multicolumn{4}{|l|}{$<10^{-10}$} \\
\hline Lsmeans & & & & & \multicolumn{2}{|l|}{ Control } & \multicolumn{2}{|c|}{ Cadmium } \\
\hline Habitat | Treatment & & & & & \multicolumn{2}{|l|}{0.74} & \multicolumn{2}{|c|}{0.011} \\
\hline Lsmeans & Paris & Paris2 & Lyon & Bordeaux & Paris & Paris2 & Lyon & Bordeaux \\
\hline Treatment| Location & $<10^{-3}$ & $<10^{-3}$ & $<10^{-4}$ & $<10^{-4}$ & $<10^{-4}$ & $<10^{-4}$ & $<10^{-4}$ & $<10^{-4}$ \\
\hline
\end{tabular}

\section{$23 \quad$ Table S2: Effect of the different factors and their interactions on the mortality rate of field workers}

24 and the emergence rate of lab workers. Fisher scores and associated p-values are from ANOVAs

25 between generalized linear models including or excluding the factor or interaction.

\begin{tabular}{|c|c|}
\hline & $\begin{array}{l}\text { Size of } \\
\text { lab workers }\end{array}$ \\
\hline Colony size & $\begin{array}{l}X_{I}=12.52 \\
<10^{-3}\end{array}$ \\
\hline Size of field workers & $\begin{array}{l}X_{I}=1.42 \\
0.23\end{array}$ \\
\hline Colony size : Treatment & $\begin{array}{l}X_{I}=0.08 \\
0.76\end{array}$ \\
\hline $\begin{array}{l}\text { Size of field } \\
\text { workers } \\
\text { :Treatment }\end{array}$ & $\begin{array}{l}X_{l}=0.23 \\
0.62\end{array}$ \\
\hline Treatment : Location & $\begin{array}{l}X_{3}=9.87 \\
0.019\end{array}$ \\
\hline Treatment : Habitat & $\begin{array}{l}X_{1}=5.03 \\
0.025\end{array}$ \\
\hline Treatment & $\begin{array}{l}X_{I}=48 \\
4.10^{-12}\end{array}$ \\
\hline Habitat & $X_{I}=4.29$ \\
\hline
\end{tabular}




\begin{tabular}{lllll}
\hline & $\mathbf{0 . 0 3 8}$ & & \\
\hline Location & $\boldsymbol{X}_{3}=\mathbf{4 2 . 1 3}$ & & & \\
& $<\mathbf{1 0}^{-8}$ & & & \\
& & & & \\
\hline Treatment | Habitat & City & & Forest & \\
& $<\mathbf{1 0}^{-4}$ & & $<\mathbf{1 0}^{-4}$ & \\
\hline Lsmeans & Paris & Paris2 & Lyon & Bordeaux \\
Treatment $\mid$ Location & $<\mathbf{1 0}^{-4}$ & $<\mathbf{1 0}^{-4}$ & $\mathbf{0 . 0 0 2 6}$ & $\mathbf{1 0}^{-4}$
\end{tabular}

26 Table S3: Effect of the different factors and their interactions on the size and the development

27 duration of lab workers. $\mathrm{Chi}^{2}$ scores and associated $\mathrm{p}$-values are from ANOVAs between generalized

28 linear models including or excluding the factor or interaction. 